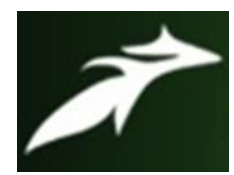

Neha Kumari et al, International Journal of Advances in Agricultural Science and Technology,

Vol.7 Issue.12, December-2020, pg. 29-36

\title{
Knowledge of the Farmers towards Adoption of Recommended Jute Production Practices in Kishanganj District of Bihar
}

\author{
Neha Kumari $^{1^{*}}$; Dr. Dipak Kumar Bose ${ }^{2}$; Dr. Jahanara ${ }^{3}$ \\ ${ }^{1}$ P.G. Student* (vandana269.269@ gmail.com); ${ }^{2}$ Associate Professor; ${ }^{3}$ Professor \& Head \\ Department of Agricultural Extension \& Communication, Naini Agriculture Institute, Sam Higginbottom \\ University of Agriculture, Technology and Sciences, Prayagraj (Allahabad)-211007, Uttar Pradesh \\ DOI: 10.47856/ijaast.2020.v07i12.005
}

\begin{abstract}
The research was conducted in Kochadhaman block of Kishanganj district of Bihar. The purpose of the study was to assist the Socio-economic profile of the Jute growers and the knowledge regarding the recommended Jute production practices. Kochadhaman block was purposely selected due to maximum production of June in this block. Ten villages were randomly selected from the block and 120 respondents were selected from twelve villages which were selected randomly. The results shows that majority of the respondents were from medium level of progressiveness, medium level of risk bearing capacity, it was found that majority (50.84\%) of the respondent belongs to low level of socio-economic status, followed by 40.83 per cent and 08.33 per cent respondents belongs to medium and high Level of socio-economic status respectively. Majority (55.84\%) of the respondent has medium Level of knowledge, followed by 28.33 per cent respondents has low and remaining 15.83 per cent of respondents has high level of knowledge. It was found that respondents were having high knowledge in land preparation, sowing time, harvesting methods, retting process, fiber extraction and marketing, medium knowledge in improve varieties, seed rate, depth of sowing, NPK ratio, FYM application, Irrigation management, insect pest control measures. It was found positive correlation between annual income, education, progressiveness with knowledge of the respondents.

KEYWORDS: Socio-economic, Knowledge, Cultivation Practices, Jute.
\end{abstract}

\section{INTRODUCTION}

Jute is a natural fiber, popularly known as the "Golden fiber" because of its colour and high cash value. It is one of the cheapest and the strongest of all natural fibers and considered as fiber of the future. Jute is second only to cotton in world's production of textile fibers. India, Bangladesh, China and Thailand are the leading producers of Jute. It is also produced in southwest Asia and Brazil. The jute fiber is also known as Pat, kosta, Nalita, Bimli or Mesta (kenaf). Jute is produced primarily from plants in the genus Corchorus belongs to the family Malvaceae. The primary source of fiber is Corchorus olitorius (Tossa jute) and the other is Corchorus capsularis (White Jute). 


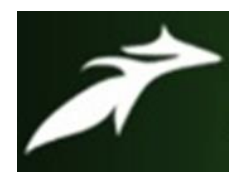

Neha Kumari et al, International Journal of Advances in Agricultural Science and Technology, Vol.7 Issue.12, December-2020, pg. 29-36

ISSN: 2348-1358

Impact Factor: 6.057

NAAS Rating: 3.77

India is the largest producer of jute goods in the world, while Bangladesh is the largest cultivator of raw jute. The cultivation of Jute in India is mainly confined to the eastern region states - West Bengal, Bihar, Assam, Tripura, Meghalaya, Orissa and Uttar Pradesh. Nearly 50 percent of total raw jute production in India alone figures in West Bengal. India is the largest Jute producer crop in the world, with 7.63 lakh hectare land; India produced 10962000 bales of $180 \mathrm{~kg}$ each. Bihar is Jute's $2^{\text {nd }}$ highest producing state in India covering 1.08 lakh hectare of land with the total production of 1571000 bales, which contributes $14.70 \%$ of total jute production in India. With an approximate area of 5.36 lakh hectare and total production of 8350000 , with 75.305 of total jute production, and 0.79 lakh hectare land with the total production of 824000 bales, with $8.0 \%$ of total jute production, West Bengal is the largest jute producer Bihar and Assam comes in second and third respectively. Three states namely West Bengal, Bihar and Assam contribute approximately $98 \%$ of total production of Jute in the country. (Source: Price Policy for Jute 2019-20).

With keeping the above detail in background, the present study was conducted at the Kochadhaman block of Kishanganj district of Bihar during the year 2019 with objective of knowledge of recommended Jute production practices.

\section{RESEARCH METHODOLOGY}

Kishanganj district was purposely selected for present study because maximum production. Kochadhaman block was purposely selected because of its maximum area under Jute cultivation. 10 villages were selected purposely on the basis of maximum area under Jute cultivation. From each selected village 12 respondents were selected randomly Thus total of 120 respondents were selected for present study. The primary data was collected with the help of personal interview technique with the help of pre-structured interview schedule designed especially in the light of objectives set up for the study. Secondary data was collected from books, journal, library, documents and government websites etc.

The dependent variable in the context of the present study was knowledge of recommended Jute production practices. The selected independent variables were grouped on the basis of 


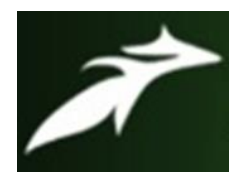

Neha Kumari et al, International Journal of Advances in Agricultural Science and Technology,

Vol.7 Issue.12, December-2020, pg. 29-36

ISSN: 2348-1358

Impact Factor: 6.057

NAAS Rating: 3.77

socio-economic, socio-psychological and extension communication characteristics. The acceptability of an innovation to an individual depends on its permissibility to his socioeconomic and psychological orientation. Thus in the present study, the selection of independent variables were made to include following characters under socio-economic, socio-psychological nature, age, education, land holding, Annual income, family size, social participation, extension contact, Mass media exposure, progressiveness, risk bearing capacity.

Person's Correlation statistical test was applied as per the nature of the data. The collected data was transformed into score for tabulation and analysis in the light of objectives to draw the logical conclusion.

\section{RESULTS AND DISCUSSION}

Results and discussion deal with frequency, percentage, average, distribution of various economic and psychological characteristics of the Jute grower as well as the correlation of scientific Jute cultivation with the Knowledge of growers.

Table-1: Socio Economic Profile of the respondents.

\begin{tabular}{|c|c|c|c|c|}
\hline S.N & \multicolumn{2}{|c|}{ Socio-economic Profile } & Frequency & Percentage \\
\hline \multirow[t]{3}{*}{1.} & \multirow[t]{3}{*}{ Age } & Young (20-35) & 29 & 24.17 \\
\hline & & Middle (36-55) & 42 & 35.00 \\
\hline & & $(>56)$ & 49 & 40.83 \\
\hline \multirow[t]{6}{*}{2.} & \multirow[t]{6}{*}{ Education } & Illiterate & 40 & 33.33 \\
\hline & & Primary & 14 & 11.67 \\
\hline & & Junior H.S & 31 & 25.83 \\
\hline & & High School & 20 & 16.67 \\
\hline & & Intermediate & 10 & 08.33 \\
\hline & & Graduate \& above & 05 & 04.17 \\
\hline \multirow[t]{3}{*}{3.} & \multirow[t]{3}{*}{ Land Holding } & $<1$ hectare & 67 & 55.84 \\
\hline & & 1-2 hectare & 40 & 33.33 \\
\hline & & $>2$ hectare & 13 & 10.83 \\
\hline \multirow[t]{3}{*}{4.} & \multirow[t]{3}{*}{ Annual Income } & $<50,000$ & 44 & 36.67 \\
\hline & & $50,001-100,000$ & 50 & 41.67 \\
\hline & & $>100,000$ & 26 & 21.66 \\
\hline \multirow[t]{2}{*}{5.} & \multirow[t]{2}{*}{ Family Type } & Nuclear & 75 & 62.50 \\
\hline & & Joint & 45 & 37.50 \\
\hline
\end{tabular}




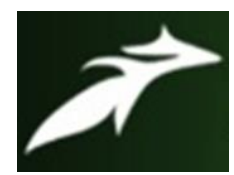

Neha Kumari et al, International Journal of Advances in Agricultural Science and Technology,

Vol.7 Issue.12, December-2020, pg. 29-36

ISSN: 2348-1358

Impact Factor: 6.057

NAAS Rating: 3.77

\begin{tabular}{|c|c|c|c|c|}
\hline \multirow[t]{3}{*}{6.} & \multirow[t]{3}{*}{ Social Participation } & No Membership & 88 & 73.34 \\
\hline & & Membership of 1 organization & 28 & 23.33 \\
\hline & & 2 or more Membership org. & 04 & 03.33 \\
\hline \multirow[t]{3}{*}{7.} & \multirow[t]{3}{*}{ Extension Contact } & Low & 60 & 50.00 \\
\hline & & Medium & 47 & 39.17 \\
\hline & & High & 13 & 10.83 \\
\hline \multirow[t]{3}{*}{8.} & \multirow{3}{*}{$\begin{array}{l}\text { Mass Media } \\
\text { Exposure }\end{array}$} & Low & 70 & 61.67 \\
\hline & & Medium & 40 & 30.00 \\
\hline & & High & 10 & 08.33 \\
\hline \multirow[t]{3}{*}{9.} & \multirow[t]{3}{*}{ Progressiveness } & Low & 11 & 09.67 \\
\hline & & Medium & 68 & 56.67 \\
\hline & & High & 41 & 34.16 \\
\hline \multirow[t]{3}{*}{10.} & \multirow{3}{*}{$\begin{array}{l}\text { Risk Bearing } \\
\text { Capacity }\end{array}$} & Low & 08 & 06.67 \\
\hline & & Medium & 63 & 52.50 \\
\hline & & High & 49 & 40.83 \\
\hline
\end{tabular}

The above table shows that 40.83 per cent of the respondents were from the Old age group, majority $(76.67 \%)$ respondents were literate, majority of the respondents $(55.84 \%)$ belongs to marginal land holding group, 41.67 per cent respondents earning was between 50,001100,000, majority (62.50\%) respondents were from nuclear family, majority (73.34\%) respondents has no membership of any organization, 50 per cent of the respondents belongs to low extension contact group, majority (61.67\%) respondents belongs to low mass media exposure group, majority of the respondents were belongs to medium level of progressiveness $(56.57 \%)$ and risk bearing capacity $(52.50 \%)$.

Table-2: Over all Socio Economic Status of the respondents.

\begin{tabular}{|c|c|c|c|}
\hline S. N & Status & Frequency & Percentage \\
\hline $\mathbf{1 .}$ & Low & 49 & 40.83 \\
\hline $\mathbf{2 .}$ & $\begin{array}{c}\text { Medium } \\
(26-31)\end{array}$ & 61 & 50.84 \\
\hline $\mathbf{3 .}$ & $\begin{array}{c}\text { High } \\
(32-38)\end{array}$ & 10 & 08.33 \\
\hline $\mathbf{4 .}$ & Total & $\mathbf{1 2 0}$ & $\mathbf{1 0 0 . 0 0}$ \\
\hline
\end{tabular}

Table-2 indicates that majority (50.84\%) of the respondent belongs to Medium Level of Socio Economic Status, followed by 40.83 per cent and 08.33 per cent respondents belongs to Low and High Level of Socio Economic Status respectively. Similar findings also reported by Sadat et al (2017) 


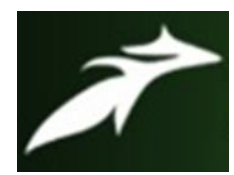

Neha Kumari et al, International Journal of Advances in Agricultural Science and Technology, Vol.7 Issue.12, December-2020, pg. 29-36

ISSN: 2348-1358

Impact Factor: 6.057

NAAS Rating: 3.77

Table-3: Knowledge of the respondents regarding improved Jute Production Practices.

\begin{tabular}{|c|c|c|c|c|}
\hline S.N & Particulars & FC & $\mathbf{P C}$ & NC \\
\hline 1. & $\begin{array}{l}\text { Land preparation: Ploughing and cross-harrowing 3-5 times } \\
\text { followed by planking }\end{array}$ & $\begin{array}{c}116 \\
(96.67)\end{array}$ & $\begin{array}{c}04 \\
(03.33)\end{array}$ & $\begin{array}{c}00 \\
(00.00)\end{array}$ \\
\hline 2. & Improved varieties ( JRO204, JRO8432, CO58 and S19 ) & $\begin{array}{c}32 \\
(26.67)\end{array}$ & $\begin{array}{c}88 \\
(73.33)\end{array}$ & $\begin{array}{c}00 \\
(00.00)\end{array}$ \\
\hline 3. & ed rate (Line sowing-5kg, Broadcasting- $7 \mathrm{~kg}$ )/ ha & $\begin{array}{c}16 \\
(13.33)\end{array}$ & $\begin{array}{c}80 \\
(66.67)\end{array}$ & $\begin{array}{c}24 \\
(20.00)\end{array}$ \\
\hline 4. & $(2.5-3 \mathrm{~cm})$ & $\begin{array}{c}14 \\
(11.67)\end{array}$ & $\begin{array}{c}66 \\
(55.00)\end{array}$ & $\begin{array}{c}40 \\
(33.33)\end{array}$ \\
\hline 5. & (arch-June) & $\begin{array}{c}106 \\
(88.33)\end{array}$ & $\begin{array}{c}12 \\
(10.00)\end{array}$ & $\begin{array}{c}02 \\
(01.67)\end{array}$ \\
\hline 6. & Line sowing and Broadcas & $\begin{array}{c}113 \\
(94.17)\end{array}$ & $\begin{array}{c}07 \\
(05.83)\end{array}$ & $\begin{array}{c}00 \\
(00.00)\end{array}$ \\
\hline 7. & plant distance & $\begin{array}{c}27 \\
(22.50)\end{array}$ & $\begin{array}{c}91 \\
(75.83)\end{array}$ & $\begin{array}{c}02 \\
(01.67)\end{array}$ \\
\hline 8. & $\mathrm{~kg} / \mathrm{ha}$ & $\begin{array}{c}22 \\
(18.33)\end{array}$ & $\begin{array}{c}96 \\
(80.00)\end{array}$ & $\begin{array}{c}02 \\
(01.67)\end{array}$ \\
\hline 9. & nes/ha) & $\begin{array}{c}41 \\
(34.16)\end{array}$ & $\begin{array}{c}65 \\
(54.17)\end{array}$ & $\begin{array}{c}14 \\
(11.67)\end{array}$ \\
\hline 11. & nagement $(50 \mathrm{~cm}$ of water for growth and & $\begin{array}{c}11 \\
(09.17)\end{array}$ & $\begin{array}{c}108 \\
(90.00)\end{array}$ & $\begin{array}{c}01 \\
(00.83) \\
\end{array}$ \\
\hline 12. & $\begin{array}{l}\text { Major insect-pest: Jute Semilooper, Stem Weevil, Yellow Mite, } \\
\text { Bihar Hairy caterpillar, etc. }\end{array}$ & $\begin{array}{c}38 \\
(31.66)\end{array}$ & $\begin{array}{c}70 \\
(58.33)\end{array}$ & $\begin{array}{c}12 \\
(10.00)\end{array}$ \\
\hline 13. & $\begin{array}{l}\text { Control methods: Endosulfan @ } 2 \mathrm{ml} / \mathrm{l} \text { or Chlorpyriphos @ } 1 \\
\mathrm{ml} / \mathrm{l} \text { to spray twice. Cypermethrin } 25 \text { per cent EC @ } 1-1.2 \mathrm{ml} / \mathrm{lit} \text {, } \\
\text { Fenvalerate } 20 \text { per cent EC @ } 1 \mathrm{ml} / \mathrm{lit}\end{array}$ & $\begin{array}{c}28 \\
(23.33)\end{array}$ & $\begin{array}{c}64 \\
(53.33)\end{array}$ & $\begin{array}{c}28 \\
(23.33)\end{array}$ \\
\hline 14. & $\begin{array}{l}\text { Major Disease: Seedling Blight, Damping off, Collar Rot, Stem } \\
\text { Rot, Root Rot, etc. }\end{array}$ & $\begin{array}{c}38 \\
(31.67)\end{array}$ & $\begin{array}{c}50 \\
(41.67)\end{array}$ & $\begin{array}{c}32 \\
(26.66)\end{array}$ \\
\hline 15. & $\begin{array}{l}\text { Control methods: Seed treatment with Carbendazim @ } 2 \mathrm{~g} / \mathrm{kg} \text { or } \\
\text { Mancozeb @ } 5 \mathrm{~g} / \mathrm{kg} \text { or T. viridi @ } 10 \mathrm{~g} / \mathrm{kg} \text {. In standing crop } \\
\text { spraying of Carbedazim } 0.2 \% \text { or Copper oxychloride } 0.75 \% \text {. }\end{array}$ & $\begin{array}{c}22 \\
(18.33)\end{array}$ & $\begin{array}{c}26 \\
(21.67)\end{array}$ & $\begin{array}{c}72 \\
(60.00)\end{array}$ \\
\hline 16. & $\begin{array}{l}\text { Retting process: usually in } 23 \text { layers and tied together, kept in } 30 \\
\mathrm{~cm} \text { deep water at a temperature of } 34^{\circ} \mathrm{C}\end{array}$ & $\begin{array}{c}73 \\
(60.83)\end{array}$ & $\begin{array}{c}27 \\
(22.50)\end{array}$ & $\begin{array}{c}20 \\
(16.67)\end{array}$ \\
\hline 17. & $\begin{array}{l}\text { Ribbon retting: modern retting process, ribbons are stripped out } \\
\text { mechanically from the stem of mature jute plants, coiled and } \\
\text { allowed to ret under water. (reduces retting time by } 4-5 \text { days and } \\
\text { improves fibre quality) }\end{array}$ & $\begin{array}{c}09 \\
(07.50)\end{array}$ & $\begin{array}{c}30 \\
(25.00)\end{array}$ & $\begin{array}{c}81 \\
(67.50)\end{array}$ \\
\hline 18. & $\begin{array}{l}\text { Fibre extraction methods: Single plant extraction method, Beat- } \\
\text { break-jerk method }\end{array}$ & $\begin{array}{c}107 \\
(89.17)\end{array}$ & $\begin{array}{c}09 \\
(07.50)\end{array}$ & $\begin{array}{c}04 \\
(03.33) \\
\end{array}$ \\
\hline 19. & $\begin{array}{l}\text { Grading: } 6 \text { parameters namely, strength, defect, root content, } \\
\text { colour, fineness and density. As per BIS specification there are } \\
\text { eight grade classification of jute, i.e., W1/TD1 to W8/TD8 }\end{array}$ & $\begin{array}{c}59 \\
(49.17)\end{array}$ & $\begin{array}{c}55 \\
(45.83)\end{array}$ & $\begin{array}{c}06 \\
(05.00)\end{array}$ \\
\hline
\end{tabular}




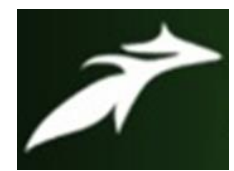

Neha Kumari et al, International Journal of Advances in Agricultural Science and Technology,

Vol.7 Issue.12, December-2020, pg. 29-36

ISSN: 2348-1358

Impact Factor: 6.057

NAAS Rating: 3.77

The table 3 shows that the jute growers has full knowledge of Land preparation (96.67\%), Sowing methods (94.17\%), Sowing time (88.33\%), Fiber extraction (89.17), and Retting process (60.83\%). Partial knowledge of Irrigation management (90.00\%), NPK ratio (75.83\%), Improved varieties (73.33\%) and Seed rate (66.67\%). Low knowledge about, Ribbon retting (67.50\%) and Disease control measure (60.00\%).

Table-4: Overall knowledge of the respondents for Jute Production Practices.

\begin{tabular}{|c|c|c|c|}
\hline S. $\mathbf{N}$ & $\begin{array}{c}\text { Knowledge } \\
\text { level }\end{array}$ & Frequency & Percentage \\
\hline $\mathbf{1}$ & $\begin{array}{c}\text { Low } \\
(24-32)\end{array}$ & 34 & 28.33 \\
\hline $\mathbf{2}$ & $\begin{array}{c}\text { Medium } \\
(33-44)\end{array}$ & 67 & 55.84 \\
\hline $\mathbf{3}$ & $\begin{array}{c}\text { High } \\
(41-48)\end{array}$ & 19 & 15.83 \\
\hline $\mathbf{4}$ & Total & $\mathbf{1 2 0}$ & $\mathbf{1 0 0 . 0 0}$ \\
\hline
\end{tabular}

Table-4 indicates that majority $(55.84 \%)$ of the respondent has Medium Level of Knowledge, followed by 28.33 per cent respondents has Low Level of Knowledge, and remaining 15.83 per cent of respondents has High Level of Knowledge. Similar finding also reported by Maraddi et al (2014)

Table-5: Correlation Coefficient between selected profiles of the respondents with knowledge:

\begin{tabular}{|c|c|}
\hline Socio-Economic Profile & Correlation Coefficient (r) \\
\hline Age & $-0.138 \mathrm{NS}$ \\
\hline Education & $0.692^{* *}$ \\
\hline Land Holding & $0.305^{*}$ \\
\hline Annual Income & $0.880^{* *}$ \\
\hline Family Type & $0.0182 \mathrm{NS}$ \\
\hline Social Participation & $0.067 \mathrm{NS}$ \\
\hline Extension Contact & $0.533^{*}$ \\
\hline Mass Media Exposure & $0.305^{*}$ \\
\hline Progressiveness & $0.649^{* *}$ \\
\hline Risk Bearing Capacity & $0.444^{*}$ \\
\hline
\end{tabular}

**Strongly significant, *moderately significant, NS non-significant

The above table shows that the annual Income (0.88), Education (0.69), Progressiveness (0.65), Extension Contact (0.53) and Risk Bearing Capacity (0.44), Land Holding (0.31) and 


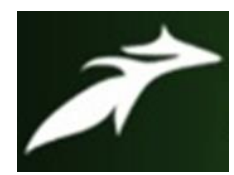

Neha Kumari et al, International Journal of Advances in Agricultural Science and Technology, Vol.7 Issue.12, December-2020, pg. 29-36

ISSN: 2348-1358

Impact Factor: 6.057

NAAS Rating: 3.77

Mass Media Exposure (0.31) is found significantly correlated with the knowledge of the respondents towards the jute production practices. So it can be concluded that Annual Income, Education, Progressiveness, Extension Contact, Risk Bearing Capacity, Land Holding, and Mass Media Exposure influence the knowledge of the respondents towards the recommended production practices of Jute.

However, the Family Type (0.018NS) and Social Participation (0.06NS) are positively and non-significantly correlated with the knowledge respondents towards the recommended production practices of Jute. So it can be concluded that Family Type and Social Participation are not influence the respondents towards the knowledge of the recommended production practices of Jute.

Whereas, Age (-0.138) non-significantly correlated with knowledge of the respondents about recommended production practices of Jute. So it can be concluded that Age is not influence the knowledge level of the respondents about recommended production practices.

Through this study it can be inferred that knowledge of recommended Jute production practices is largely depend upon the socio-economic, social participation, Mass media exposure and psychological characteristics of Jute grower. The finding is in the line of the finding of Mondal and Bandyopadhyay (2014).

\section{CONCLUSION}

It was concluded that majority of the respondents were literate, middle age group, land holding up to 1 hectare, and income between 50,001-100,000. They have medium level of progressiveness and majority of the respondents were not connected with any social organization. The overall socio-economic statuses of the respondents were medium level. It was also observed that respondents have medium level of knowledge regarding improved jute production practices. It was found that education, annual income, extension contact, mass media exposure, and progressiveness were positively correlated with knowledge of the respondents. Government should take proper steps and appropriate extension strategies to be followed for improved knowledge of the respondents which will lead to the all-round development of the area. 


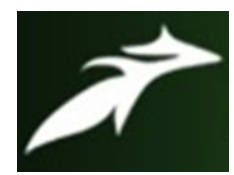

Neha Kumari et al, International Journal of Advances in Agricultural Science and Technology,

Vol.7 Issue.12, December-2020, pg. 29-36

ISSN: 2348-1358

Impact Factor: 6.057

NAAS Rating: 3.77

\section{REFERENCES}

[1]. Gohil, G. R. Nakum, P. B. Kalsariya, B. N. and Patel, R. I. (2016) Knowledge level of cotton growers about crisis management for cotton cultivation ,Gujarat, India, International Journal of Agriculture Sciences ISSN: 0975-3710 \& E -ISSN :09759107 , Volume 8, Issue $25,2016$.

[2]. Islam, M. M. and Rehman, M. M. (2013) Advances in Jute and allied fibres postharvest processing technologies in Bangladesh: Adoption constraints, prospect and future thrust in Dhaka, Bangladesh, Research WebPub Vol. 1(2), pp. 20-30.

[3]. Islam, M. M. Xiaoying, J. Uddin , E.M. and Bhuiyan, F. (2015) Status and constraints of jute cultivation in Bangladesh: An experience from selected upazilas under chandpur district, Bangladesh, Asian Journal of Agriculture and Rural Development, 5(8)2015: 175-186.

[4]. Maraddi, G. N. Vanishree and Sathish, H. S. (2014) Analysis of farmer's knowledge and adoption of improved cotton cultivation practices, Raichur, India, Agriculture Update, Vol. 9(1), pp. 1-6.

[5]. Mondal, D. and Bandyopadhyay, A. K. (2014) Adoption of Jute Production Technology in West Bengal, India: Economic Affairs: Vol. 59 Special Issue: 701-709.

[6]. Sadat, A. and Chakraborty, K.(2017) Farmers Knowledge, Perceptions and practices in jute insect pest management and cultural strategy in the upper Gangetic plains of West Bengal, India: Indian J .Agric .Res ., 51(4)2017:320-326.

[7]. Sadat, A. Ghosh, S. K. and Chakraborty, K. (2017) Impact of training on Knowledge and Adoption of Jute technology in Uttar Dinajpur district of West Bengal, India: IndianRes.J.Ext.Edu,17(2) pp 73-77.

[8]. Sheheli, S. and Roy, B. (2014) Constraints and opportunities of raw jute production: a household level of analysis in Bangladesh, Progressive Agriculture 25: 38-46. 